\title{
Family Violence and the Caring Professions
}




\title{
Family Violence and the Caring Professions
}

\author{
Edited by \\ PAUL KINGSTON \\ and \\ BRIDGET PENHALE
}

Foreword by Olive Stevenson

MACMILLAN 
Selection, editorial matter, Introduction, Chapters 9 and 10, and Conclusion

(C) Paul Kingston and Bridget Penhale 1995

Individual chapters (in order)

(c) Christine Hallett, Stephanie Wheeler, Jim Ogg and Jonathan Dickens, Norman Johnson, Jan Pahl, Siobhan Lloyd, Chris Phillipson and Simon Biggs,

G. C. H. Bennett 1995

Foreword @ Olive Stevenson 1995

All rights reserved. No reproduction, copy or transmission of this publication may be made without written permission.

No paragraph of this publication may be reproduced, copied or transmitted save with written permission or in accordance with the provisions of the Copyright, Designs and Patents Act 1988, or under the terms of any licence permitting limited copying issued by the Copyright Licensing Agency, 90 Tottenham Court

Road, London W1P 9HE.

Any person who does any unauthorised act in relation to this publication may be liable to criminal prosecution and civil claims for damages.

First published 1995 by

MACMILLAN PRESS LTD

Houndmills, Basingstoke, Hampshire RG21 2XS

and London

Companies and representatives

throughout the world

ISBN 978-0-333-60001-6

ISBN 978-1-349-13306-2 (eBook)

DOI 10.1007/978-1-349-13306-2

A catalogue record for this book is available from the British Library.

$\begin{array}{llllllllll}10 & 9 & 8 & 7 & 6 & 5 & 4 & 3 & 2 & 1\end{array}$

$\begin{array}{llllllllll}04 & 03 & 02 & 01 & 00 & 99 & 98 & 97 & 96 & 95\end{array}$ 
Foreword by Olive Stevenson

Acknowledgements

Introduction: Family Violence: Framing the Issues

Paul Kingston and Bridget Penhale

\section{PART I CHILD ABUSE}

1. Child abuse: an academic overview Christine Hallett

2. Child abuse: the health perspective Stephanie Wheeler

3. Social perspectives in child abuse Jonathan Dickens and Jim Ogg

\section{PART II ADULT ABUSE}

4. Domestic violence: an overview

Norman Johnson

5. Health professionals and violence against women Jan Pahl

6. Social work and domestic violence Siobhan Lloyd 


\section{PART III ELDER ABUSE}

7. Elder abuse: a critical overview

Chris Phillipson and Simon Biggs

8. Health perspectives and elder abuse

G. C. H. Bennett

9. Social perspectives on elder abuse

Bridget Penhale and Paul Kingston

10. Conclusion : Similarities, Differences and Synthesis

Bridget Penhale and Paul Kingston

Bibliography

Index 
This book is overdue. It offers to British readers for the first time a systematic analysis of abuse to three different categories of people - children, spouses/partners (usually women) and old people - and offers a valuable comparison of the three. Even that bald description hints at the difficulties with which the editors had to grapple. Is it 'ageist' to separate out old people from other adults? What about adults with particular disabilities, especially learning difficulties? And so on. It is a minefield, conceptually and ethically. But all the more credit is due for the decision to grasp the nettle.

The specialist focus on specific groups in nearly all of the literature so far is understandable. Different political and social issues have been on the agenda, different professionals and workers engaged in different ways. However, there was clearly a pressing need for an overview, academically and professionally. The strength of the book is that it does not attempt to 'emulsify' the three groups but tackles each in turn, drawing out in its conclusions, similarities and differences. I have been puzzled in the past by the apparent reluctance to do this. In some quarters, notably governmental, there may be a fear that comparisons of other abuse with child abuse may open a Pandora's Box of trouble and unleash demands for resources. Amongst some academic and professional specialists with elderly people may be a reluctance to get sucked into the world of child abuse which has been so dominant and so voracious. The field of domestic abuse has been less professionalised (an interesting phenomenon in itself) and this has led to a curious split in thought between violence to women and violence to children - so often occurring in the same family and caused by the same man. The "discourses' have run parallel but have not met in any significant way.

Whatever explanations one advances, the result is unfortunate. It is not a question of stressing similarities; it is a question of using the knowledge and experience gained from one field of study to illuminate 
another. This book offers rich opportunities to do this and it is particularly useful to have the health and social perspectives presented in turn. Again, rarely do we see these side by side in the same book.

There would seem to be six dimensions in which comparisons are fruitful. These concern: social attitudes to the phenomenon; definitions of it; etiology; the development of a policy response, including law and procedures; assessment processes; and intervention, including evaluation. Each in turn reveals similarities and differences which affect the course of events. For example, it is clear that the plight of abused old people has not raised the same social concern as that of children which suggests fundamental differences in the value accorded to the two groups. Yet we can also usefully remind ourselves that the level and extent of denial of varying dimensions, including sexual, of child abuse only two or three decades years ago may parallel contemporary reluctance to grapple with this in the field of elder abuse.

Again, in relation to domestic violence, definitions and etiology have been dominated by the feminist paradigm of patriarchal domination, to a far greater extent than the other two groups. Yet this should remind us, first, that a significant number of 'old-age abuse' cases simply carry on a long-standing pattern of marital violence and, secondly, that this way of looking at the phenomenon has a great deal to say to us in relation to child abuse.

When we consider the highly developed law available to us in child protection and the woeful inadequacy of protective law for adults, we have tested legal models to consider (do we want emergency protection orders? for example) but also a responsibility to acknowledge the difference between children and adults in terms of concepts of legal competence with a crucially differing balance between autonomy and protection.

More generally, how can we ensure that assessment of elder abuse takes its proper place within the general framework of community care without excessive prominence, as has happened in child abuse, and that it does not become procedurally driven to the detriment of a sensitive professional response?

These are simply brief examples designed to show how fruitful comparisons are in stimulating high-quality debate among academics and professionals. What is now needed is for specific areas of comparison to be further developed. This book offers numerous such opportunities. It should be warmly welcomed. 
There are a number of people without whom this book would not have been possible. The original concept derives from the earlier American works of Straus, Gelles, and Steinmetz et al. to whom we are indebted. Early discussions followed from the initial contact at Action on Elder Abuse, and introduction to each other by Gerry Bennett - our special thanks to him. An initial approach to Kerry Lawrence at Macmillan proved favourable and positive. Our subsequent editor Margaret O'Gorman has proved flexible but committed, for which we are thankful.

Contributors to the book were relatively straightforward to locate: no coercion proved necessary! All have been positive, co-operative and steadfast and produced work of a high quality; our thanks to all. Thanks also to Professor Olive Stevenson for her foreword.

Bridget wishes to thank Dr Shulamith Ramon and Professor Peter Wedge for their initial faith and continuing belief; Ruth and Jenny for their interest and discussions; Dan, Ben and Nick for their unfailing support; and Paul for his commitment to the book/task and his trust and belief that we would complete it.

Paul wishes to thank the friendship and encouragement of Rosalie Wolf and Karl Pillemer and many other American colleagues who continue to keep in contact and consistently stimulate ideas, including Terry Fulmer and Tanya Johnson. Gerry Bennett requires special acknowledgement for his friendship and advice as does Chris Phillipson for his support and provocative ideas that always take the debate forward. Thanks also to all the steering group of Action on Elder Abuse whose ideas continually refresh the family violence debate.

Finally a personal thanks to Ang, Zoe, Lenna and Wookie who continue to tolerate my absences both in England and America. 
G. C. J. Bennett is Senior Lecturer, London Hospital Medical College, Consultant Physician Health Care of the Elderly CELFACS (City and East London Family and Community Health Services) and Honorary Consultant, Royal Hospital Trust. Chair of Action on Elder Abuse and co-author of Elder Abuse: Concepts, Theories and Interventions. Research interests include the epidemiology of abuse and carer perspectives on the issue. Other interests include being co-director of a joint would-care unit with research into all chronic wounds. Other books include Alzheimer's Disease and Other Confusional States, Essentials of Health Care of the Elderly and Wound Care: A Practitioners' Guide.

Simon Biggs worked as a community psychologist before becoming Programme Co-ordinator to the Central Council for Education and Training in Social Work. He has a wide experience of groupwork with service users, students and professional workers. He is the author of Understanding Ageing and co-author of Understanding Elder Abuse: A Training Manual for Helping Professions.

Jonathan Dickens and Jim Ogg qualified respectively in social work at the Universities of Nottingham and London in 1987. They met as part-time students at the MSc social research course, University of Surrey in 1989, and have both undertaken social work research. Jim Ogg has been a Team Leader with Essex Department of Social Services since March 1994. He has a special interest in the rights of vulnerable older people. Jonathan Dickens has worked as a social worker in an inner London Borough and was a Legal Officer for a London Local Authority until April 1994, acting on behalf of the Social Services Department in court proceedings relating to the care and protection of children. 
Christine Hallett is Reader in Social Policy and Head of Department of Applied Social Science at the University of Stirling Scotland. She has researched and published extensively in the field of child protection (with Dr Elizabeth Birchall) and case conferences (with Professor Olive Stevenson). She is currently engaged on a study of decision-making in the Children's Hearings system in Scotland and is Chair of the Child Protection Committee in Central Region, Scotland.

Norman Johnson is Professor of Public Policy at the University of Portsmouth. For four years he was Deputy Director of the Keele research project into marital violence. In 1985 he edited a book entitled Marital Violence. He has published several books and numerous papers in the area of social policy.

Paul Kingston is a Research Fellow in the Department of Applied Studies, University of Keele. He is actively involved in research on abuse of elderly people in both England and America. He is Honorary Treasurer of Action on Elder Abuse. Research interests include family violence, falls in the elderly and elderly care in the Accident and Emergency Department. Publications include a co-authored text (with Gerry Bennett) Elder Abuse: Concepts, Theories and Interventions and Elder Abuse: Health and Social Perspectives.

Siobhan Lloyd is a Lecturer in Sociology/Women's Studies at the University of Aberdeen. She is also Head of the University Counselling Service. Her main research is in the area of violence against women. She has recently completed, with Michele Burman, a study for the Scottish Officer of specialist police units for the investigation of violent crime against women and children.

Jan Pahl is Director of Research at the National Institute for Social Work and an Honorary Reader at the University of Kent. Her research on battered women was funded by the Department of Health and was published in numerous articles and as a book: Private Violence and Public Policy. Jan Pahl has worked as a consultant on the topic of violence against women with the United Nations, the World Health Organisation and the Commonwealth Secretariat. She spent six years as a researcher in the health service and is an honorary member of the faculty of Public Health Medicine. Her present job at the National Institute for Social Work involves directing a programme of research on social work and social care, funded by the Department of Health. 
Bridget Penhale is currently Team Leader of a team of Hospital Social Workers for the Social Services Department, Norfolk County Council. Prior to this post she held a joint appointment post between the School of Social Work, University of East Anglia, and Norfolk Social Services (1990-2): lecturing part-time and practising as a social worker with older people part-time. With a first degree in psychology, she qualified as a social worker (LSE) in 1981. She has specialised in work with older people since 1984. Her interest in elder abuse arose from practice but was developed through her academic post. She is Vice-Chair of Action on Elder Abuse, Chair of BASW Sub-committee on Community Care (1992-5) and a member of the Executive committee of BASW's Special Interest Group on Ageing. Publications include a number of refereed articles and Elder Abuse: Health and Social Perspectives, Macmillan.

Chris Phillipson is Professor of Applied Social Studies and Social Gerontology at Keele University and Head of Department. He has published seven books concerned with social, political and health issues arising from an ageing society. His research interests include: the political economy of health and ageing, community care of older people, health education/promotion, drugs and the elderly, old-age abuse and professional training and education. $\mathrm{He}$ is a regular consultant to the Health Education Authority, a past executive member of the British Association for Services to the Elderly. He has recently published a study of the future of work and retirement (with Frank Laczko) and a training manual on elder abuse Understanding Elder Abuse: A Training Manual for Helping Professions (Simon Biggs).

Stephanie Wheeler is Senior Lecturer at Bournemouth University. Her background has involved general nursing, midwifery and health visiting. In health visiting she spent ten years in the community as a practising health visitor and later a manager. She currently leads the professional studies theme in the Institute of Health and Community Services. She teaches primarily health care ethics and law for nursing and other undergraduate courses and is particularly interested in qualitative research. 